\title{
The Metabolism of IgE in Patients with Immunodeficiency States and Neoplastic Conditions
}

\author{
Atsushi Iio, Warren Strober, Samuel Broder, Stephen H. Polmar, \\ and THOMAS A. WALDMANN \\ From the Metabolism Branch and Immunology Branch, National Cancer Institute, National Institutes \\ of Health, Bethesda, Maryland 20014
}

A B S T R A C T Serum IgE concentrations were determined and IgE turnover studies were performed in control individuals as well as in patients with several disease states. Patients with common variable hypogammaglobulinemia, thymoma and hypogammaglobulinemia, ataxia telangiectasia, and selective IgA deficiency had significantly decreased mean serum IgE concentrations. In turnover studies, this was found to be due to decreased IgE synthesis. In spite of these depressed mean values, some patients with common variable hypogammaglobulinemia had normal serum IgE concentrations and synthetic rates.

Patients with the Wiskott-Aldrich syndrome had a significantly elevated mean serum IgE concentration. In one of four patients studied with the turnover technique, a strikingly high IgE concentration was present and was associated with an elevated IgE synthetic rate. Three other patients had both normal serum IgE concentrations and synthetic rates.

Patients with chronic lymphocytic leukemia had significantly decreased mean serum concentrations and synthetic rates for IgE. The depressed IgE synthesis was associated with a significantly prolonged IgE half-life.

Patients with Hodgkin's disease had significantly increased serum IgE concentrations. One of three patients studied had a high serum IgE concentration and synthetic rate of IgE. The two other patients had normal serum IgE concentrations associated with normal synthetic rates.

Finally, patients with protein-losing enteropathy or familial hypercatabolic hypoproteinemia had normal IgE concentrations associated with normal IgE metabolic parameters. In these cases, the disorder

Dr. Polmar's present address is Department of Pediatrics, Case Western Reserve University School of Medicine, Cleveland, Ohio.

Received for publication 10 February 1976 and in revised form 8 December 1976.

The Journal of Clinical Investigation in the catabolic rate was not severe enough to affect the total amount of circulating $\mathrm{IgE}$ because IgE normally has a very high fractional catabolic rate.

In general, IgE levels in a variety of disease states were correlated with IgE synthetic rates and abnormalities in the catabolic rate of $\mathrm{IgE}$ in disease did not exert an important effect on $\operatorname{IgE}$ concentration.

\section{INTRODUCTION}

In 1966 Ishizaka and co-workers demonstrated that human reaginic antibody is associated with a distinct class of immunoglobulin, subsequently designated IgE (1). Independently, Johansson and Bennich described a myeloma protein (ND) ${ }^{1}$ that was antigenically identical to IgE (2); later, a second IgE myeloma protein (PS) was detected by Ogawa and co-workers (3). The isolation of these myeloma proteins permitted the definition of the chemical characteristics of IgE molecules and the development of a variety of radioimmunoassays for the quantitation of serum IgE levels.

The serum concentration of any plasma protein, including IgE, is determined by its rate of synthesis and rate of catabolism as well as its distribution pattern. Pathologic processes affect these metabolic parameters in characteristic ways and this gives rise in turn to characteristic alterations in serum protein levels. Metabolic turnover studies with purified radioiodinated proteins of four of the major classes of immunoglobulin molecules (IgG, IgA, IgM, and IgD) have allowed the definition of the metabolic characteristics of these immunoglobulin classes and have led to the identification of disorders of these metabolic parameters in disease $(4,5)$.

In the present paper we report on the metabolic

\footnotetext{
${ }^{1} \mathrm{ND}$ and PS refer to the IgE proteins used in the turnover study and their source in this paper.
} 
TABLE I

\begin{tabular}{|c|c|c|c|}
\hline Patients & $\begin{array}{c}\text { Number of } \\
\text { patients studied }\end{array}$ & Serum mean* & IgE Concentration I \\
\hline & & $n g / m l$ & $n g / m l$ \\
\hline Controls & 74 & 96 & $24-386$ \\
\hline $\begin{array}{l}\text { Common variable hypogamma- } \\
\text { globulinemia }\end{array}$ & 36 & $11 \S$ & $3.24-38.9$ \\
\hline $\begin{array}{l}\text { Thymoma and hypogamma- } \\
\text { globulinemia }\end{array}$ & 9 & $4.4 \S$ & $3.4-6.0$ \\
\hline Chronic lymphotic leukemia & 32 & $18.4 \S$ & $3.5-96$ \\
\hline Myeloma IgG paraprotein & 16 & $27.4 \S$ & $11-71$ \\
\hline Myeloma IgA paraprotein & 17 & $35.9 \S$ & $7.5-172$ \\
\hline Macroglobulinemia of & & & \\
\hline Waldenström & 56 & 67.3 & $15-305$ \\
\hline Ataxia telangiectasia & 44 & $12 \S$ & $3.6-40$ \\
\hline Selective IgA deficiency & 25 & $35 \S$ & $5.6-214$ \\
\hline Intestinal lymphangiectasia & 10 & $112 \S$ & $18.6-676$ \\
\hline Wiskott-Aldrich syndrome & 12 & $3,475 \S$ & $499-24,257$ \\
\hline Hodgkin's disease & 19 & $945 \S$ & $162-5,512$ \\
\hline
\end{tabular}

characteristics of $\mathrm{IgE}$ in a variety of disease states that give rise to both reduced and elevated serum IgE concentrations. These studies include patients with a generalized defect in immunoglobulin synthesis, patients with deficient synthesis of one or two immunoglobulin classes, patients with accelerated endogenous catabolism of one or more classes of immunoglobulin molecules, patients with excessive loss of immunoglobulin molecules into the gastrointestinal tract, and finally, patients with excessive synthesis of one or more classes of polyclonal immunoglobulin molecules. These metabolic studies define the disorder accounting for the IgE abnormality in the patients studied and bring into focus many of the factors which control IgE synthesis, catabolism, and distribution.

\section{METHODS}

Patients. 43 patients with various immunologic and neoplastic disorders were investigated with IgE metabolic turnover studies. This group consisted, in part, of patients with primary immunodeficiency classified according to the criteria of The World Health Organization and included eight patients with common variable hypogammaglobulinemia, three patients with thymoma and hypogammaglobulinemia, three patients with ataxia telangiectasia, four patients with selective IgA deficiency, and four patients with the WiskottAldrich syndrome. The patients with neoplastic disease included seven patients with chronic lymphocytic leukemia, three patients with Hodgkin's disease, and five patients with IgG, IgA myeloma, or Waldenström's macroglobulinemia. Also studied were five patients with protein-losing enteropathy secondary to intestinal lymphangiectasia and one patient with familial hypercatabolic hypoproteinemia.

Control patients in the IgE metabolic turnover studies consisted of 10 patients with neuromuscular or neoplastic diseases who were suitable for study because they had normal serum IgE concentrations and because groups of patients with comparable disorders had normal serum IgE levels. These patients included one patient with malignant melanoma, one patient with the adult Fanconi syndrome, and eight patients with various neuromuscular disorders. Their ages ranged from 11 to $63 \mathrm{yr}$; seven were male and three were female. None of the patients in these groups had a history of allergic disorders, skin conditions, or evidence of parasitic infestation.

Serum IgE levels were determined on larger groups of patients with these different clinical states (Table I). Pertinent clinical data concerning these patients are listed in Tables II-VI. All patients and controls gave informed consent to the performance of the turnover studies.

Preparation of labeled IgE. Plasma from a patient (PS) with IgE myeloma given to us by Dr. O. R. McIntyre (Department of Medicine, Dartmouth Medical School, Hanover, N. H.) served as the source of purified IgE in the majority of turnover studies. The plasma was dialyzed against 0.01 M Tris, $\mathrm{pH} 8.0,0.02 \mathrm{M} \mathrm{NaCl}$ buffer, and applied to a DEAE cellulose column equilibrated with the same buffer. (Whatman Inc., Clifton, N. J.) The column was then eluted with the starting buffer to obtain a broad protein peak and then eluted with $0.01 \mathrm{M}$ Tris, pH $8.0,0.06 \mathrm{M} \mathrm{NaCl}$ buffer to obtain a second protein peak; this peak consisted of pure IgE as shown in Ouchterlony double diffusion analysis by using goat antisera to human IgE, IgG, IgA, IgM, albumin transferrin, and whole serum (Melroy Laboratories, Springfield, Va.). A number of studies were also performed with an IgE preparation purified from the serum of patient ND by Drs. Johansson and Bennich (University Hospital, Uppsala, Sweden) and kindly given to us. This preparation was also tested by Ouchterlony analysis and found to be immunochemically pure.

The purified IgE was labeled with ${ }^{125}$ I or ${ }^{131}$ I by McFarlane's iodide monochloride method (6). Unbound radioiodide was removed by dialysis against pyrogen-free 0.15 
$\mathrm{M} \mathrm{NaCl}$. All preparations had an average of less than 2 atoms of iodide per molecule of IgE. The specific activity was approximately $2 \mathrm{mCi} / \mathrm{mg}$. The iodinated IgE was tested for pyrogenicity in rabbits, diluted in human serum albumin to prevent radiation damage, and sterilized by passage through a $0.22-\mu \mathrm{m}$ Millipore filter. (Millipore Corp., Bedford, Mass.)

Protocol of turnover study. All patients were hospitalized on the wards of the Clinical Center of the National Institutes of Health during the period of study. Over this period they were clinically stable and their serum IgE concentration remained constant. Therefore, the patients were considered to be in a steady state with regard to IgE metabolism. They received five drops of saturated potassium iodide solution three times a day during the study to prevent thyroidal uptake of radioiodine. The study was begun by administration of 5-25 $\mu \mathrm{Ci}$ of labeled IgE intravenously from a calibrated syringe. Serum samples were collected at $10 \mathrm{~min}$, at $4 \mathrm{~h}$, and daily for 7 to 14 days; complete 24-h urine specimens were collected each $24 \mathrm{~h}$. Serum and urine samples as well as a measured dilution of the administered dose were counted with a gamma ray well-type scintillation counter with a thallium-activated sodium iodide crystal.

Serum IgE concentration was measured by double antibody radioimmunoassay according to the method described previously (7). The minimum measurable concentration by this assay is $4 \mathrm{ng} / \mathrm{ml}$.

Data analysis. The total circulating IgE, the fraction of intravascular IgE catabolized per day (fractional catabolic rate of $\operatorname{IgE}$ ), and the absolute catabolic rate of $\operatorname{IgE}$ (synthetic rate of IgE) were determined by the methods of Nosslin (8) and Matthews (9). Accordingly, the fractional catabolic rate $(\mathrm{FCR})^{2}$ was calculated from the reciprocal of the area under the serum decay curve and the percent of total exchangeable IgE in the intravascular pool was obtained by dividing the area under the serum decay curve by the area under the whole body decay curve. The plasma volume was obtained by dividing the value for the amount of radioactivity in the injected dose by the value for the amount of radioactivity in $1 \mathrm{ml}$ of plasma at zero time; the latter value was determined by extrapolation of the serum decay curve to the zero time point. The biological half-life $\left(t_{1}\right)$ was obtained graphically from the serum decay curve. The whole body decay curve was obtained by cumulative subtraction of the values for urinary radioactivity from the value for radioactivity in the injected dose. The fitting of the curves to the data and calculation of the areas under decay curves were performed with a UNIVAC 1108 digital computer. (Univac Div. Sperry Rand Corp., Philadelphia, Pa.) Mean values for the serum IgE concentration, total circulating IgE pool, and the absolute metabolic rate for IgE were obtained as geometric means. Mean values for the percent intravascular pool, the half-time survival $\left(t_{t}\right)$, and the fractional catabolic rate were obtained as arithmetic means. Significance of the difference between means was evaluated by Welch's $t$ test.

\section{RESULTS}

IgE metabolism in control individuals. As shown in Table II, the geometric serum IgE concentration in 10 control individuals was $111 \mathrm{ng} / \mathrm{ml}$. This is associated with a wide $68 \%$ confidence interval of $38-323$

\footnotetext{
${ }^{2}$ Abbreviation used in this paper: FCR, fractional catabolic rate.
}

$\mathrm{ng} / \mathrm{ml}$. Metabolic studies with ${ }^{125} \mathrm{I}-\mathrm{IgE}$ disclosed that this serum $\operatorname{IgE}$ concentration was associated with a total circulating IgE value of $4.1 \mu \mathrm{g} / \mathrm{kg}$ and a total body IgE pool of $10.2 \mu \mathrm{g} / \mathrm{kg}$. The IgE survival was quite short with a mean half-time of $2.7 \pm 0.8$ days. This corresponded to a fractional catabolic rate of $94 \pm 25 \%$ of the plasma pool per day. The absolute amount of IgE catabolized per day was $3.8 \mu \mathrm{g} / \mathrm{kg}$ with a $68 \%$ interval of $1.2-12.4 \mu \mathrm{g} / \mathrm{kg}$; in the steady state this is equal to the amount of IgE synthesized per day.

Diseases with decreased synthesis of all immunoglobulin classes: common variable immunodeficiency. The geometric mean IgE concentration of 36 patients with common variable immunodeficiency studied was markedly reduced to a value of $11.0 \mathrm{ng} / \mathrm{ml}$ (Table I). 28 of the patients had an IgE concentration of less than $15 \mathrm{ng} / \mathrm{ml}$, a value falling below the 10 th percentile of the values in the normal population; these patients were thus considered to be $\operatorname{IgE}$ deficient. Eight of the patients, however, had normal IgE serum concentrations of $28,31,54,70,100,132,220$, and $380 \mathrm{ng} / \mathrm{ml}$. IgE metabolic studies were performed on eight patients with common variable hypogammaglobulinemia, including those with extreme reductions of IgE concentrations as well as those with $\operatorname{IgE}$ concentrations in the normal range. These eight patients had a geometric mean IgE level of $9.4 \mathrm{ng} / \mathrm{ml}$ and a $68 \%$ confidence interval of 2.8-32 ng/ml (Table II). No IgE was detectable in the serum of four of these patients (i.e., concentration less than $3.9 \mathrm{ng} / \mathrm{ml}$ ). In metabolic turnover studies the plasma volume of these patients was not significantly greater than that of the control individuals. Therefore, the total circulating $\operatorname{IgE}$ of the patients (mean $0.41 \mu \mathrm{g} / \mathrm{kg}$ ) was significantly decreased compared to that of controls (mean $4.1 \mu \mathrm{g} / \mathrm{kg}, P$ $<0.001)$. The $\operatorname{IgE}$ in these patients distributed normally between the intra- and extravascular pools and the mean survival time and mean fractional catabolic rate for IgE were not significantly different from the corresponding values in control individuals. On the other hand, the mean synthetic rate for $\operatorname{IgE}$ in the patients with common variable hypogammaglobulinemia was only $0.32 \mu \mathrm{g} / \mathrm{kg}$ per day, a value approximately $8 \%$ of the mean value obtained in controls. Therefore, the decreased amount of IgE in the body pool of such patients is due to decreased synthesis of IgE and is not due to increased catabolism of this immunoglobulin.

While the mean values for serum IgE concentration, total circulating IgE and IgE synthetic rate in the patients with common variable hypogammaglobulinemia are decreased as compared to normal values, 8 of the 36 patients had normal serum IgE concentrations and 3 of the 8 patients studied with metabolic turnover studies had normal values for serum $\operatorname{IgE}$ 
TABLE II

IgE Metabolism in Common Variable Hypogammaglobulinemia and Thymoma with Hypogammaglobulinemia

\begin{tabular}{|c|c|c|c|c|c|c|c|c|c|c|c|c|}
\hline \multirow[b]{2}{*}{ Patient } & \multirow[b]{2}{*}{ Age } & \multirow[b]{2}{*}{ Sex } & \multirow{2}{*}{$\begin{array}{c}\text { Serum } \\
\text { IgE con- } \\
\text { centration }\end{array}$} & \multirow{2}{*}{$\begin{array}{l}\text { Plasma } \\
\text { volume }\end{array}$} & \multirow{2}{*}{$\begin{array}{l}\text { Total } \\
\text { circulating } \\
\text { IgE }\end{array}$} & \multirow{2}{*}{$\begin{array}{l}\text { Intra- } \\
\text { vascular }\end{array}$} & \multirow{2}{*}{$\begin{array}{c}\text { Survival } \\
\mathrm{T}_{\mathbf{t}}\end{array}$} & \multirow{2}{*}{$\begin{array}{c}\text { Fractional } \\
\text { catabolic } \\
\text { rate* }^{*}\end{array}$} & \multirow{2}{*}{$\begin{array}{l}\text { Synthetic } \\
\text { rate }\end{array}$} & \multicolumn{3}{|c|}{ Serum concentration } \\
\hline & & & & & & & & & & IgG & IgA & $\operatorname{IgM}$ \\
\hline & & & $n g / m l$ & $m l / k g$ & $\mu g / k g$ & $\%$ & Days & & $\mu g / k g / d a y$ & $m g / m l$ & $m g / m l$ & $m g / m l$ \\
\hline \multicolumn{13}{|l|}{ Controls (10) } \\
\hline $\begin{array}{l}\text { Mean } \ddagger \\
68 \% \text { Confid }\end{array}$ & & & 111 & 37.9 & 4.1 & 40.6 & 2.7 & 0.94 & 3.8 & 8.1 & 2.4 & 1.1 \\
\hline interval & & & $38-323$ & $30.9-44.8$ & $1.2-13.9$ & $28.2-53.1$ & $2.0-3.5$ & $0.69-1.19$ & $1.2-12.4$ & $6.0-11.0$ & $1.7-3.3$ & $0.78-1.62$ \\
\hline \multicolumn{13}{|c|}{ Common variable hypogammaglobulinemia } \\
\hline K. G. & 23 & $\mathrm{~F}$ & $<3.9$ & 42.9 & $<0.17$ & 37.9 & 2.3 & 1.04 & $<0.17$ & 0.5 & 0.17 & 0 \\
\hline D. J. & 37 & $\mathrm{~F}$ & $<3.9$ & 51.2 & $<0.20$ & 28.2 & 1.8 & 1.03 & $<0.21$ & 1.4 & 0 & 0.21 \\
\hline G. W. & 43 & $\mathrm{~F}$ & $<3.9$ & 39.8 & $<0.16$ & 26.7 & 4.8 & 0.92 & $<0.15$ & 0.70 & 0 & 0 \\
\hline M. P. & 51 & $\mathrm{~F}$ & $<3.9$ & 38.3 & $<0.13$ & 24.1 & 4.9 & 0.88 & $<0.12$ & 1.05 & 0 & 0.052 \\
\hline S. F. & 39 & $\mathbf{M}$ & 5.1 & 58.6 & 0.30 & 31.5 & 3.3 & 0.92 & 0.27 & 2.2 & 0 & 0 \\
\hline P. B. & 24 & $\mathbf{M}$ & 28 & 42.1 & 1.18 & 25.7 & 3.1 & 0.64 & 0.75 & 1.45 & 0 & 0 \\
\hline M. C. & 18 & $F$ & 30.5 & 35.3 & 1.08 & 38.6 & 2.4 & 0.64 & 0.69 & 4.7 & 0.42 & 0.68 \\
\hline J. L. & 30 & M & 70 & 40.9 & 2.86 & 47.4 & 3.7 & 0.47 & 1.34 & 0.6 & 0 & 0 \\
\hline Mean & & & 9.4 & 43.6 & 0.41 & 32.5 & 3.3 & 0.82 & 0.32 & 1.21 & - & - \\
\hline $\begin{array}{l}68 \% \text { Confiden } \\
\text { interval }\end{array}$ & & & $2.8-32$ & $36.0-51.2$ & $0.13-1.30$ & $24.4-40.6$ & $2.2-4.4$ & $0.61-1.03$ & $0.13-0.79$ & $0.58-2.54$ & & \\
\hline & & & $P \S<0.001$ & & $P<0.001$ & & & & $P<0.001$ & & & \\
\hline \multicolumn{13}{|c|}{ Thymoma and hypogammaglobulinemia } \\
\hline S. L. & 55 & $\mathbf{F}$ & $<2.0$ & 44.7 & $<0.09$ & 31.2 & 3.1 & 0.49 & $<0.044$ & 1.8 & 0.44 & 0 \\
\hline O. $O$. & 56 & $\mathbf{F}$ & $<3.4$ & 47.9 & $<0.16$ & 39.8 & 3.8 & 0.75 & $<0.12$ & 1.5 & 0 & 0 \\
\hline E. H. & 55 & $\mathbf{M}$ & $<2.0$ & 66.0 & $<0.13$ & 14.5 & 4.0 & 0.89 & $<0.12$ & 2.65 & 0.71 & 0.039 \\
\hline & & & \multicolumn{9}{|c|}{$68 \%$ Confidence } & - \\
\hline interval & & & $1.8-3.2$ & $41.4-64.4$ & $0.09-0.16$ & $15.6-41.4$ & $3.1-4.1$ & $0.51-0.91$ & $0.05-0.15$ & $1.4-2.6$ & & \\
\hline & & & $P<0.001$ & $P<0.02$ & $P<0.001$ & & & & $P<0.001$ & & & \\
\hline
\end{tabular}

* Fraction of total intravascular IgE per day.

t The mean values of serum IgE concentration, total circulating IgE, synthetic rate and serum concentrations of IgG, IgA, and IgM are expressed as geometric means. $\$$ Statistical significance of difference between the means in controls and disease group.

concentration. These patients also had values for the IgE total circulating pool size and IgE synthetic rates that were within the $90 \%$ confidence interval of the normal population. Thus, in these patients, metabolic parameters for IgE were much closer to normal values than corresponding values for other immunoglobulins. In other words, the concentration and metabolism of IgE may be discordant with that of other immunoglobulins in certain patients with hypogammaglobulinemia.

Thymoma and hypogammaglobulinemia. The serum IgE level was markedly depressed in all the patients with thymoma and hypogammaglobulinemia studied. No IgE was detectable in the serum of eight of the nine patients with thymoma and reduction of all other classes of immunoglobulins. In the remaining patient the IgE level was only $8 \mathrm{ng} / \mathrm{ml}$. Similarly, no IgE was detectable in the serum of the two patients with thymoma and markedly reduced serum concentrations of IgG and IgA but significantly elevated serum concentrations of IgM. Metabolic turnover studies were performed in three patients with thymoma and hypogammaglobulinemia in whom no serum IgE was detectable (Table II). In these studies the thymoma patients were found to have significantly increased plasma volumes compared to those of control individuals (mean value of $52.9 \pm 11.5 \mathrm{ml} / \mathrm{kg}$ vs. normal mean of $37.9 \pm 7.0 \mathrm{ml} / \mathrm{kg} ; P<0.02$ ) and this was associated with decreased circulating IgE pools. The serum survival $t_{\frac{1}{2}}$ of $\operatorname{IgE}$ was somewhat prolonged to 3.6 days but the fractional catabolic rate was not significantly different from that in control individuals. Finally, the synthetic rate was less than $1 / 40$ of that of control individuals and thus, the strikingly low serum IgE was due to decreased synthesis of IgE and not to excessive catabolism of this immunoglobulin.

Chronic lymphocytic leukemia. In general, the serum levels of IgE were reduced in patients with neoplasms affecting B lymphocytes or plasma cells. Thus, the IgE levels of 32 patients with chronic lymphocytic leukemia were extremely reduced with a geometric mean serum IgE concentration of $18 \mathrm{ng} / \mathrm{ml}$, a value that differed significantly from that of the normal population $(P<0.001)$. In $63 \%$ of the patients with chronic lymphocytic leukemia IgE was below $15 \mathrm{ng} / \mathrm{ml}$, that is, below the 10th percentile for normal 
adults. IgE metabolic turnover studies were performed on seven of the patients with chronic lymphocytic leukemia (Table III). The serum IgE concentration of these patients was generally decreased with a geometric mean of $10.7 \mathrm{ng} / \mathrm{ml}$ and a $68 \%$ confidence interval of $3.3-35.4 \mathrm{ng} / \mathrm{ml}$. In these turnover studies, increased plasma volumes averaging $72.2 \pm 26.4 \mathrm{ml} / \mathrm{kg}$ were found; however, total circulating $\operatorname{IgE}$ was still significantly decreased with a geometric mean of 0.74 $\mu \mathrm{g} / \mathrm{kg}$ and $\mathrm{a} 68 \%$ interval of $0.25-2.15 \mu \mathrm{g} / \mathrm{kg}(P<0.01)$. Of considerable interest is the fact that this patient group had a significantly prolonged mean serum survival time and decreased fractional catabolic rate: the mean values for these parameters were $3.6 \pm 0.9$ days $(P<0.05)$ and $65 \pm 14 \%(P<0.02)$, respectively. The synthetic rate was significantly decreased compared to control values with a geometric mean of $0.74 \mu \mathrm{g} / \mathrm{kg}$ per day $(P<0.01)$. In all, the decreased serum IgE resulted from the severely impaired syn- thesis of IgE which was associated with, but not fully compensated by, an increase in IgE survival.

Multiple myeloma and Waldenström's macroglobulinemia. The mean IgE concentration was significantly lower than normal $(P<0.05)$ in patients with multiple myeloma associated with an IgG or IgA paraprotein. 16 patients with multiple myeloma and an IgG paraprotein had a geometric mean serum IgE concentration of $27 \mathrm{ng} / \mathrm{ml}$ and the 17 patients with multiple myeloma and IgA paraprotein had a geometric mean IgE level of $36 \mathrm{ng} / \mathrm{ml}$. 56 patients with Waldenström's macroglobulinemia had a geometric mean IgE level of $67 \mathrm{ng} / \mathrm{ml}$. Although this value is lower than the control mean, the difference is not significant $(P>0.05)$. IgE turnover studies were performed in two patients with IgG myeloma, one patient with IgA myeloma, and two patients with Waldenström's macroglobulinemia (Table III). These studies included two patients, one with IgG myeloma and

TABLE III

IgE Metabolism in Chronic Lymphocytic Leukemia and Myeloma

\begin{tabular}{|c|c|c|c|c|c|c|c|c|c|c|c|c|}
\hline \multirow[b]{2}{*}{ Patient } & \multirow[b]{2}{*}{ Age } & \multirow[b]{2}{*}{ Sex } & \multirow{2}{*}{$\begin{array}{l}\text { Serum } \\
\text { IgE con- } \\
\text { centration }\end{array}$} & \multirow{2}{*}{$\begin{array}{l}\text { Plasma } \\
\text { volume }\end{array}$} & \multirow{2}{*}{$\begin{array}{c}\text { Total } \\
\text { circulating } \\
\text { IgE }\end{array}$} & \multirow{2}{*}{$\begin{array}{c}\text { Intra- } \\
\text { vascular }\end{array}$} & \multirow{2}{*}{$\begin{array}{c}\text { Survival } \\
\mathrm{t}_{\mathbf{l}}\end{array}$} & \multirow{2}{*}{$\begin{array}{c}\text { Fractional } \\
\text { catabolic } \\
\text { rate }^{*}\end{array}$} & \multirow{2}{*}{$\begin{array}{l}\text { Synthetic } \\
\text { rate }\end{array}$} & \multicolumn{3}{|c|}{ Serum concentration } \\
\hline & & & & & & & & & & IgG & IgA & $\operatorname{IgM}$ \\
\hline & & & $n g / m l$ & $m l / k g$ & $\mu g / k g$ & $\%$ & Days & & $\mu g / k g / d a y$ & $m g / m l$ & $m g / m l$ & $m g / m l$ \\
\hline \multicolumn{13}{|l|}{ Controls } \\
\hline Mean $\downarrow$ & & & 111 & 37.9 & 4.13 & 40.6 & 2.7 & 0.94 & 3.77 & 8.1 & 2.4 & 1.1 \\
\hline \multicolumn{13}{|c|}{$68 \%$ Confidence } \\
\hline level & & & $38-323$ & $30.9-44.8$ & $1.23-13.92$ & $28.2-53.1$ & $2.0-3.5$ & $0.69-1.19$ & $1.15-12.35$ & $6.0-11.0$ & $1.7-3.3$ & $0.78-1.62$ \\
\hline \multicolumn{13}{|c|}{ Chronic lymphocytic leukemia } \\
\hline L. S. & 67 & $\mathrm{~F}$ & 3.2 & 114.7 & 0.37 & 21.7 & 3.3 & 0.69 & 0.75 & 5.1 & 0.95 & 1.2 \\
\hline D. C. & 63 & $\mathbf{F}$ & $<3.4$ & 99.3 & $<0.34$ & 36.8 & 4.1 & 0.49 & $<0.16$ & 3.6 & 0.11 & 0.094 \\
\hline A. $\mathbf{M}$. & 61 & $\mathbf{F}$ & $<5.8$ & 46.1 & $<0.27$ & 32.3 & 4.7 & 0.59 & $<0.16$ & 8.2 & 3 & 0.4 \\
\hline I. P. & 62 & $\mathrm{~F}$ & 9.6 & 51.7 & 0.50 & 42.7 & 3.7 & 0.62 & 0.31 & 9.3 & 0.49 & 0.094 \\
\hline A. E. & 5.5 & $\mathbf{F}$ & 10.5 & 63.3 & 0.67 & 39.9 & 2.3 & 0.86 & 0.57 & 9 & 2.8 & 0.475 \\
\hline D. R. & 70 & $\mathbf{M}$ & 31 & 78.6 & 2.44 & 40.9 & 4.6 & 0.79 & 1.91 & 3.5 & 0.89 & 0.085 \\
\hline S. $\mathbf{K}$. & 61 & $\mathrm{~F}$ & 84 & 51.9 & 4.36 & 41.8 & 2.7 & 0.50 & 2.18 & 6.0 & 0.58 & 0.31 \\
\hline Mean & & & 10.7 & 72.2 & 0.74 & 36.6 & 3.6 & 0.65 & 0.74 & 6.0 & 0.81 & 0.24 \\
\hline \multicolumn{13}{|c|}{$68 \%$ Confidence } \\
\hline \multirow[t]{2}{*}{ interval } & & & $3.3-3.5 .4$ & $45.8-98.6$ & $0.25-2.15$ & $29.1-44.1$ & $2.7-4.5$ & $0.51-0.79$ & $0.20-2.15$ & $3.9-9.0$ & $0.26-2.49$ & $0.09-0.68$ \\
\hline & & & $P \S<0.01$ & $P<0.01$ & $P<0.01$ & & $P<0.05$ & $P<0.02$ & $P<0.01$ & & & \\
\hline \multicolumn{13}{|l|}{ IgG myeloma } \\
\hline J. P. & 63 & $\mathrm{~F}$ & $<3.9$ & 57.2 & $<0.22$ & 40.2 & 2.9 & 0.49 & $<0.11$ & 23 & 0.145 & 0.17 \\
\hline M. K. & 50 & $\mathrm{~F}$ & 68 & 51.9 & 3.53 & 49.7 & 3.7 & 0.55 & 1.93 & 42 & 0.4 & 0.79 \\
\hline \multicolumn{13}{|l|}{ IgA myeloma } \\
\hline R. T. & 18 & $\mathbf{M}$ & 44 & 5.5 & 2.44 & 57.7 & 2.3 & 0.67 & 1.64 & 6.4 & 25 & 0.68 \\
\hline \multicolumn{13}{|c|}{ Waldenström's macroglobulinemia } \\
\hline J. W. & 54 & $\mathbf{M}$ & 4.8 & 61.9 & 0.30 & 28.3 & 1.9 & 1.04 & 0.31 & 1.05 & 0.10 & 20 \\
\hline S. B. & 67 & $\mathrm{~F}$ & 150 & 43.5 & 6.52 & 39.0 & 3.7 & 0.74 & 4.8 & 7.0 & 0.17 & 27 \\
\hline Mean & & & 24.3 & 54.0 & 1.30 & 43.0 & 2.9 & 0.70 & 0.88 & $4.8^{\prime \prime}$ & $0.18^{11}$ & $0.45^{\prime \prime}$ \\
\hline \multicolumn{13}{|c|}{$68 \%$ Confidence } \\
\hline \multirow[t]{2}{*}{ interval } & & & $4.7-125$ & $47.1-60.9$ & $0.28-5.97$ & $31.8-54.2$ & $2.1-3.7$ & $0.49-0.91$ & $0.19-4.03$ & $0.9-26.2$ & $0.1-0.32$ & $0.19-1.05$ \\
\hline & & & & $P<0.001$ & & & & & & & & \\
\hline
\end{tabular}

* Fraction of total intravascular IgE per day.

$\downarrow$, $\$$ Same as described in Table II.

"Geometric mean was calculated excluding the values of patients with paraproteins of the same immunoglobulin class. 
TABLE IV

IgE Metabolism in Ataxia Telangiectasia and Selective IgA Deficiency

\begin{tabular}{|c|c|c|c|c|c|c|c|c|c|c|c|c|}
\hline \multirow[b]{2}{*}{ Patient } & \multirow[b]{2}{*}{ Age } & \multirow[b]{2}{*}{ Sex } & \multirow{2}{*}{$\begin{array}{l}\text { Serum } \\
\text { IgE con- } \\
\text { centration }\end{array}$} & \multirow{2}{*}{$\begin{array}{l}\text { Plasma } \\
\text { volume }\end{array}$} & \multirow{2}{*}{$\begin{array}{c}\text { Total } \\
\text { circulating } \\
\text { IgE }\end{array}$} & \multirow{2}{*}{$\begin{array}{c}\text { Intra- } \\
\text { vascular }\end{array}$} & \multirow{2}{*}{$\underset{t_{i}}{\text { Survival }}$} & \multirow{2}{*}{$\begin{array}{c}\text { Fractional } \\
\text { catabolic } \\
\text { rate* }^{*}\end{array}$} & \multirow{2}{*}{$\begin{array}{l}\text { Synthetic } \\
\text { rate }\end{array}$} & \multicolumn{3}{|c|}{ Serum concentration } \\
\hline & & & & & & & & & & IgG & $\operatorname{IgA}$ & IgM \\
\hline & & & $n g / m l$ & $m l / k g$ & $\mu g / k g$ & $\%$ & Days & & $\mu g / k g / d a y$ & $m g / m l$ & $m g / m l$ & $m g / m l$ \\
\hline \multicolumn{13}{|l|}{ Controls (10) } \\
\hline Meant & & & 111 & 37.9 & 4.13 & 40.6 & 2.7 & 0.94 & 3.77 & 8.1 & 2.4 & 1.1 \\
\hline $\begin{array}{l}68 \% \text { Confid } \\
\text { interval }\end{array}$ & & & $38-323$ & $30.9-44.8$ & $1.23-13.92$ & $28.2-53.1$ & $2.0-3.5$ & $0.69-1.19$ & $1.15-12.35$ & $6.0-11.0$ & $1.7-3.3$ & $0.78-1.62$ \\
\hline \multicolumn{13}{|c|}{ Ataxia telangiectasia } \\
\hline M. R. & 17 & $\mathbf{M}$ & $<3.4$ & 45.5 & $<0.16$ & 37.1 & 3.9 & 0.65 & $<0.10$ & 8.3 & 5.3 & 2.2 \\
\hline K. L. & 18 & $\mathbf{M}$ & $<3.9$ & 36.0 & $<0.14$ & 39.5 & 2.7 & 0.92 & $<0.13$ & 2.6 & 0 & 6.0 \\
\hline V. C. & 17 & $\mathrm{~F}$ & $<3.9$ & 34.1 & $<0.13$ & 23.7 & 2.5 & 0.97 & $<0.13$ & 9.6 & 0 & 2.3 \\
\hline Mean & & & 3.7 & 35.5 & 0.14 & 33.4 & 3.0 & 0.85 & 0.12 & 5.9 & - & 3.1 \\
\hline \multicolumn{13}{|c|}{$68 \%$ Confidence } \\
\hline \multirow[t]{2}{*}{ interval } & & & $3.4-4.0$ & $29.4-41.6$ & $0.13-0.16$ & $24.9-41.9$ & $2.2-3.8$ & $0.68-1.02$ & $0.10-0.14$ & $2.9-12.1$ & & $1.8-5.5$ \\
\hline & & & $P \S<0.001$ & & $P<0.001$ & & & & $P<0.001$ & & & \\
\hline \multicolumn{13}{|c|}{ Selective IgA deficiency } \\
\hline B. H. & 39 & $\mathbf{F}$ & 4.1 & 44.1 & 0.18 & 22.5 & 3.6 & 1.07 & 0.19 & 35.8 & 0 & 0.35 \\
\hline B. $W$. & 72 & $\mathbf{M}$ & 8.4 & 42.2 & 0.35 & 26.6 & 3.0 & 0.45 & 0.19 & 10.5 & 0.31 & 0.58 \\
\hline N. I. & 61 & $\mathrm{~F}$ & 9 & 33.6 & 0.30 & 26.1 & 2.5 & 0.45 & 0.14 & 13.6 & 0 & 0.34 \\
\hline J. W. & 47 & $\mathrm{~F}$ & 12.6 & 43.7 & 0.55 & 36.8 & 1.4 & 0.77 & 0.42 & 12.8 & 0 & 1.65 \\
\hline Mean & & & 7.9 & 40.9 & 0.32 & 28.0 & 2.6 & 0.71 & 0.21 & 16.0 & - & 0.58 \\
\hline \multicolumn{13}{|c|}{$68 \%$ Confidence } \\
\hline \multirow[t]{2}{*}{ interval } & & & $4.9-12.7$ & $36.0-45.8$ & $0.20-0.51$ & $21.9-34.1$ & $1.7-3.5$ & $0.43-0.99$ & $0.13-0.34$ & $9.2-17.7$ & & $0.28-1.21$ \\
\hline & & & $P<0.001$ & & $P<0.001$ & & & & $P<0.001$ & & & \\
\hline
\end{tabular}

* Fraction of total intravascular IgE per day.

$\downarrow$, Same as described in Table II.

one with Waldenström's macroglobulinemia, with extreme reduction of IgE levels and three patients with IgE levels within the normal range. As a group, the patients showed a marginally low serum IgE concentration with a mean of $24.3 \mathrm{ng} / \mathrm{ml}$ and a $68 \%$ confidence interval of $4.7-125 \mathrm{ng} / \mathrm{ml}$. In spite of the fact that these patients exhibited an expanded plasma volume with a mean of $54.0 \pm 6.9 \mathrm{ml} / \mathrm{kg}$, the total circulating IgE was decreased slightly with a mean total circulating IgE of $1.30 \mu \mathrm{g} / \mathrm{kg}$ and a $68 \%$ confidence interval of $0.28-5.97 \mu \mathrm{g} / \mathrm{kg}$. The survival time and fractional catabolic rate of IgE were all normal. The rate of $\operatorname{IgE}$ synthesis (mean $0.88 \mu \mathrm{g} / \mathrm{kg}$ per day, $68 \%$ confidence interval $0.19-4.03 \mu \mathrm{g} / \mathrm{kg}$ per day) was decreased in these patients compared to control values (mean $3.8 \mu \mathrm{g} / \mathrm{kg}$ per day, $68 \%$ confidence interval $1.2-12.4 \mu \mathrm{g} / \mathrm{kg}$ per day), but this decrease was not statistically significant $(P>0.1)$. The two patients with the low serum IgE levels had IgE synthetic rates lower than those observed in any of the control individuals. Thus, the decreased serum IgE concentrations observed in some myeloma patients are derived from impaired IgE synthesis.

Diseases with deficient synthesis of one or two immunoglobulin classes: ataxia telangiectasia. The geometric mean serum IgE concentration of the 44 patients with ataxia telangiectasia was markedly re- duced to a value of $12 \mathrm{ng} / \mathrm{mg}$ and $80 \%$ of the patients had an IgE level of less than $15 \mathrm{ng} / \mathrm{ml}$. IgA deficiency (serum IgA $<0.2 \mathrm{mg} / \mathrm{ml}$ ) occurred in $66 \%$ of these patients. IgE turnover studies were performed in three of the patients with ataxia telangiectasia (Table IV), none of whom had detectable serum IgE. The total circulating IgE level was, therefore, below the detectable level and the synthetic rate of $\operatorname{IgE}$ was reduced to a value of less than $0.12 \mu \mathrm{g} / \mathrm{kg}$ per day, a value obtained by assuming a serum concentration equal to the minimum measurable concentration of serum IgE. On the other hand, the serum survival and fractional catabolic rates for IgE in ataxia telangiectasia patients were normal with mean values of $3.0 \pm 0.8$ days, and $85 \pm 17 \%$ of the intravascular pool per day, respectively. Therefore, the strikingly decreased IgE concentration of the ataxia telangiectasia patients originates from severely impaired synthesis of IgE.

Selective IgA deficiency. The term selective IgA deficiency is used to refer to individuals with serum IgA concentrations of $0.2 \mathrm{mg} / \mathrm{ml}$ or less with normal or elevated concentrations of serum IgG and IgM; thus individuals with selective IgA deficiency may or may not be IgE deficient as well. Serum IgE concentrations were determined in 25 patients with selective IgA deficiency. The mean IgE concentrations of these 
patients, $35 \mathrm{ng} / \mathrm{ml}$, was significantly lower than that of normal adults $(P<0.02)$. 11 of the 25 individuals of this group had IgE levels of less than $15 \mathrm{ng} / \mathrm{ml}$. Among the 25 patients with isolated IgA deficiency, 7 individuals belonged to the same family; therefore, of 18 patients in whom selective IgA deficiency has been independently ascertained, 5 or approximately $28 \%$ had associated IgE deficiency. It should be noted that the IgA deficient patients in the present study were predominantly from a population of blood bank donors. Other workers who have studied atopic patients with IgA deficiency have noted normal IgE levels in their patients (10). IgE metabolism was studied in four patients with combined IgA and IgE deficiency (Table IV). The serum IgE concentrations in these patients varied between $4.1-12.6 \mathrm{ng} / \mathrm{ml}$ with a mean of $7.9 \mathrm{ng} / \mathrm{ml}$. The total circulating IgE was also significantly decreased as was the IgE synthetic rate $(0.32$ $\mu \mathrm{g} / \mathrm{kg}$ and $0.21 \mu \mathrm{g} / \mathrm{kg}$ per day, respectively; $P<0.001$ ) when compared to control values. However, both the serum survival and fractional catabolic rate of IgE were not significantly different from those observed in control individuals. It should be noted that one of the patients with selective IgA deficiency associated with IgE deficiency and one of the patients with ataxia telangiectasia with a similar protein pattern had exceedingly short IgA survivals (along with circulating antibodies to IgA) but normal survivals of IgE. Thus, in the patients with selective IgA deficiency studied, the accompanying $\operatorname{IgE}$ deficiency is due solely to decreased IgE synthesis unassociated with shortened IgE survival.
Diseases with accelerated endogenous catabolism or excessive loss of immunoglobulins: protein-losing enteropathy. Hypogammaglobulinemia associated with a short immunoglobulin survival may occur secondary to excessive loss of plasma proteins into the urinary or gastrointestinal tract or may reflect an abnormality in endogenous catabolism of protein molecules. Thus, the serum immunoglobulin concentrations of 10 patients with excessive loss of protein into the gastrointestinal tract (protein-losing enteropathy) secondary to intestinal lymphangiectasia were significantly reduced with mean serum IgG concentration of $4.4 \mathrm{mg} / \mathrm{ml}$, mean IgA concentration of 1.04 $\mathrm{mg} / \mathrm{ml}$, and mean IgM concentration of $0.64 \mathrm{mg} / \mathrm{ml}$. On the other hand, the serum IgE level (mean 112 $\mathrm{ng} / \mathrm{ml}$ ) did not differ significantly from that obtained in normal patients $(P>0.3)$. IgE turnover studies were performed in five patients with protein-losing enteropathy secondary to intestinal lymphangiectasia (Table V). These patients had a significant loss of serum protein into the gastrointestinal tract with an average of $30.6 \%$ of the IV pool lost by this route per day as determined with ${ }^{51} \mathrm{Cr}$-albumin studies. These six patients had a mean serum IgE concentration of $61.0 \mathrm{ng} / \mathrm{ml}$ with a $68 \%$ confidence interval of 28.1-132.7 ng/ml. In metabolic turnover studies the mean value for the total circulating IgE was 2.78 $\mu \mathrm{g} / \mathrm{kg}$ in these patients, whereas the serum IgE survival and fractional catabolic rates averaged 2.8 days and $99 \%$ of the IV pool, respectively. Finally, the mean synthetic rate for IgE was $2.69 \mu \mathrm{g} / \mathrm{kg}$ per day with a $68 \%$ confidence interval of $1.32-5.51 \mu \mathrm{g} / \mathrm{kg}$ per day.

TABLE V

IgE Metabolism in Protein-Losing Enteropathy and Hypercatabolic Hypoproteinemia

\begin{tabular}{|c|c|c|c|c|c|c|c|c|c|c|c|c|}
\hline \multirow[b]{2}{*}{ Patient } & \multirow[b]{2}{*}{ Age } & \multirow[b]{2}{*}{ Sex } & \multirow{2}{*}{$\begin{array}{l}\text { Serum } \\
\text { IgE con- } \\
\text { centration }\end{array}$} & \multirow{2}{*}{$\begin{array}{l}\text { Plasma } \\
\text { volume }\end{array}$} & \multirow{2}{*}{$\begin{array}{c}\text { Total } \\
\text { circulating } \\
\text { IgE }\end{array}$} & \multirow{2}{*}{$\begin{array}{l}\text { Intra- } \\
\text { vascular }\end{array}$} & \multirow{2}{*}{$\begin{array}{c}\text { Survival } \\
t_{\mathbf{i}}\end{array}$} & \multirow{2}{*}{$\begin{array}{l}\text { Fractional } \\
\text { catabolic } \\
\text { rate* }\end{array}$} & \multirow{2}{*}{$\begin{array}{l}\text { Synthetic } \\
\text { rate }\end{array}$} & \multicolumn{3}{|c|}{ Serum concentration } \\
\hline & & & & & & & & & & IgG & $\operatorname{IgA}$ & $\operatorname{IgM}$ \\
\hline & & & $n g / m l$ & $m g / k g$ & $\mu g / k g$ & $\%$ & Days & & $\mu g / k g / d a y$ & $m g / m l$ & $m g / m l$ & $m g / m l$ \\
\hline \multicolumn{13}{|l|}{ Controls (10) } \\
\hline $\begin{array}{l}\text { Mean } \downarrow \\
68 \% \text { Confid }\end{array}$ & & & 111 & 37.9 & 4.13 & 40.6 & 2.7 & 0.94 & 3.77 & 8.1 & 2.4 & 1.1 \\
\hline interval & & & $38-323$ & $30.9-44.8$ & $1.23-13.92$ & $28.2-53.1$ & $2.0-3.5$ & $0.69-1.19$ & $1.15-12.35$ & $6.0-11.0$ & $1.7-3.3$ & $0.78-1.62$ \\
\hline \multicolumn{13}{|c|}{ Protein-losing enteropathy } \\
\hline H. W. & 21 & $\mathbf{F}$ & 28 & 60.2 & 1.68 & 24.3 & 2.9 & 0.73 & 1.22 & 6.4 & 2.3 & 1.2 \\
\hline V. R. & 23 & $\mathbf{F}$ & 31 & 41.4 & 1.28 & 36.2 & 3.3 & 1.42 & 1.82 & 4.6 & 3.5 & 2.0 \\
\hline D. S. & 13 & $\mathbf{F}$ & 52 & 40.4 & 2.10 & 51.9 & 2.4 & 0.98 & 2.06 & 7.8 & 2.25 & 0.62 \\
\hline R. B. & 15 & $\mathbf{M}$ & 150 & 33.1 & 4.97 & 55.2 & 2.1 & 0.85 & 4.24 & 4.5 & 0.8 & 0.58 \\
\hline M. M. & 51 & $\mathbf{M}$ & 125 & 58.9 & 7.36 & 42.2 & 3.2 & 0.99 & 7.29 & 5.6 & 2.0 & 0.46 \\
\hline Mean & & & 61.0 & 46.8 & 2.78 & 42.0 & 2.8 & 0.99 & 2.69 & 5.7 & 2.0 & 0.83 \\
\hline $\begin{array}{l}68 \% \text { Confiden } \\
\text { interval }\end{array}$ & & & $28.1-132.7$ & $34.7-58.9$ & $1.32-5.85$ & $29.6-54.4$ & $2.3-3.3$ & $0.73-1.25$ & $1.32-5.51$ & $4.5-7.1$ & $1.1-3.4$ & $0.45-1.52$ \\
\hline \multicolumn{13}{|c|}{ Hypercatabolic hypoproteinemia } \\
\hline W. J. & 39 & $\mathrm{~F}$ & 46 & 45.2 & 2.08 & 62.3 & 1.9 & 0.73 & 1.51 & 1.9 & 3.2 & 1.15 \\
\hline
\end{tabular}


All of these metabolic parameters were not significantly different from those obtained in controls. Thus, even in the face of a significant loss of serum proteins into the gastrointestinal tract, there was no significant decrease in the plasma pool of IgE nor in the survival $t_{t}$, nor was there a significant elevation in the fractional catabolic rate for this protein.

The serum IgE level and IgE metabolic parameters were also normal in a patient with familial hypercatabolic hypoproteinemia, a disorder with a generalized hypercatabolism of long surviving serum proteins including albumin, IgG, and IgA (Table V).

Diseases with hypergammaglobulinemia as a result of increased synthesis of immunoglobulins: Wiskott-Aldrich syndrome. 12 patients with the Wiskott-Aldrich syndrome, a disease characterized by thrombocytopenia, eczema, and a very high incidence of infections, were studied. Mean serum IgG level of the patients was $10.2 \mathrm{mg} / \mathrm{ml}$, a value quite similar to the age-matched mean value of $8.8 \mathrm{mg} / \mathrm{ml}$ in controls. Mean serum IgA levels of the patients were significantly elevated with a mean value of $3.7 \mathrm{mg} / \mathrm{ml}$ as compared to the mean value of $1.4 \mathrm{mg} / \mathrm{ml}$ in controls $(P<0.01)$. Mean serum IgM level in the patients was $0.56 \mathrm{mg} / \mathrm{ml}$, a value significantly lower than the mean value of $1.0 \mathrm{mg} / \mathrm{ml}$ observed in controls ( $P$ $<0.01$ ). The IgE levels of these 12 patients were markedly increased with a mean of $3,475 \mathrm{ng} / \mathrm{ml}$ and a
$68 \%$ confidence interval of $499-24,257 \mathrm{ng} / \mathrm{ml}$. IgE turnover studies were performed in four patients with the Wiskott-Aldrich syndrome, including one patient with an exceedingly high IgE concentration $(37,000$ $\mathrm{ng} / \mathrm{ml}$ ) and three patients with serum IgE concentrations within the normal range (Table VI). In the patient with the high serum IgE level metabolic study disclosed a total circulating IgE of $1,729 \mu \mathrm{g} / \mathrm{kg}$ and a synthetic rate of $1,089 \mu \mathrm{g} / \mathrm{kg}$ per day, values that were some 300 times normal. The fractional catabolic rate for IgE was normal in this patient. In the patients with normal serum IgE concentrations the total circulating IgE and $\operatorname{IgE}$ synthetic rate did not differ significantly from normal values. The fraction of the intravascular pool of $\operatorname{IgE}$ catabolized per day was normal in all four patients studied (92\% of the IV pool/day). These results indicate that when IgE levels are elevated in patients with the Wiskott-Aldrich syndrome, it is due to increased synthesis of this protein and, when IgE levels are normal, the parameters of IgE metabolism are normal.

Hodgkin's disease. The mean serum IgE concentration in 19 patients with Hodgkin's disease was $945 \mathrm{ng} / \mathrm{ml}$, a value significantly greater than the control value $(P<0.001)$. IgE metabolism was studied in three patients (Table VI), one with an elevated serum IgE concentration $(935 \mathrm{ng} / \mathrm{ml})$ and two with normal serum IgE concentrations ( 18.3 and $73 \mathrm{ng} / \mathrm{ml}$ ).

TABLE VI

IgE Metabolism in Wiskott-Aldrich Syndrome and Hodgkin's Disease

\begin{tabular}{|c|c|c|c|c|c|c|c|c|c|c|c|c|}
\hline \multirow[b]{2}{*}{ Patient } & \multirow[b]{2}{*}{ Age } & \multirow[b]{2}{*}{ Sex } & \multirow{2}{*}{$\begin{array}{l}\text { Serum } \\
\text { IgE con- } \\
\text { centration }\end{array}$} & \multirow{2}{*}{$\begin{array}{l}\text { Plasma } \\
\text { volume }\end{array}$} & \multirow{2}{*}{$\begin{array}{c}\text { Total } \\
\text { circulating } \\
\text { IgE }\end{array}$} & \multirow{2}{*}{$\begin{array}{c}\text { Intra- } \\
\text { vascular }\end{array}$} & \multirow{2}{*}{$\begin{array}{c}\text { Survival } \\
t_{i}\end{array}$} & \multirow{2}{*}{$\begin{array}{c}\text { Fractional } \\
\text { catabolic } \\
\text { rate* }^{*}\end{array}$} & \multirow{2}{*}{$\begin{array}{l}\text { Synthetic } \\
\text { rate }\end{array}$} & \multicolumn{3}{|c|}{ Serum concentration } \\
\hline & & & & & & & & & & IgG & $\operatorname{Ig} A$ & $\operatorname{IgM}$ \\
\hline & & & $n g / m l$ & $m l / k g$ & $\mu g / k g$ & $\%$ & Days & & $\mu g / k g / d a y$ & $m g / m l$ & $m g / m l$ & $m g / m l$ \\
\hline \multicolumn{13}{|l|}{ Controls (10) } \\
\hline Mean & & & 111 & 37.9 & 4.1 & 40.6 & 2.7 & 0.94 & 3.8 & 8.1 & 2.4 & 1.1 \\
\hline \multicolumn{13}{|c|}{$68 \%$ Confidence } \\
\hline interval & & & $38-323$ & $30.9-44.8$ & $1.2-13.9$ & $28.2-53.1$ & $2.0-3.5$ & $0.69-1.19$ & $1.2-12.4$ & $6.0-11.0$ & $1.7-3.3$ & $0.78-1.62$ \\
\hline \multicolumn{13}{|c|}{ Wiskott-Aldrich Syndrome } \\
\hline D. $O$. & 10 & $\mathbf{M}$ & 33.4 & 53.3 & 1.78 & 35.4 & 3.5 & 0.92 & 1.64 & 6.7 & 5.5 & 0.15 \\
\hline J. 0. & 11 & $\mathbf{M}$ & 104 & 55.0 & 5.72 & 34.8 & 3.5 & 1.06 & 6.06 & 8.74 & 8.5 & 0.052 \\
\hline R. $\mathbf{M}$. & 4 & $\mathbf{M}$ & 140 & 45.7 & 6.40 & 44.4 & 1.5 & 1.06 & 6.75 & 7.4 & 2.2 & 0.57 \\
\hline A. D. & 1 & $\mathbf{M}$ & 37,000 & 46.7 & 1,729 & 61.0 & 1.5 & 0.63 & 1,089 & 5.6 & 1.78 & 0.255 \\
\hline Mean & & & 366 & 50.2 & 32.1 & 43.9 & 2.5 & 0.92 & 16.4 & 7.0 & 3.7 & 0.18 \\
\hline \multicolumn{13}{|c|}{$68 \%$ Confidence } \\
\hline \multirow[t]{2}{*}{ interval } & & & $16-8,447$ & $45.5-54.8$ & $1.5-668$ & $31.7-56.1$ & $1.3-3.7$ & $0.72-1.12$ & $0.92-290$ & $5.8-8.5$ & $1.8-7.7$ & $0.07-0.50$ \\
\hline & & & & $P \S<0.01$ & & & & & & & & \\
\hline \multicolumn{13}{|c|}{ Hodgkin's disease } \\
\hline J. R. & 20 & F & 18.3 & 38.0 & 0.69 & 38.8 & 2.5 & 0.95 & 0.66 & 11.0 & 1.83 & 2.4 \\
\hline J. B. & 33 & $\mathbf{M}$ & 73 & 55.3 & 4.04 & 49.7 & 2.6 & 0.88 & 3.56 & 12.2 & 3.94 & 0.81 \\
\hline E. J. & 24 & $\mathbf{M}$ & 935 & 45.2 & 42.3 & 42.3 & 2.4 & 0.68 & 28.8 & 7.7 & 1.46 & 0.088 \\
\hline Mean & & & 108 & 46.2 & 4.9 & 43.6 & 2.5 & 0.84 & 4.08 & 10.1 & 2.19 & 0.56 \\
\hline \multicolumn{13}{|c|}{$68 \%$ Confidence } \\
\hline interval & & & $15-792$ & $37.5-54.9$ & $0.6-38.7$ & $38.0-49.2$ & $2.4-2.6$ & $0.70-0.98$ & $0.61-27.0$ & $8.0-12.8$ & $1.30-3.69$ & $0.10-2.99$ \\
\hline
\end{tabular}

* Fraction of total intravascular IgE per day.

t, $\$$ Same as described in Table II. 
TABLE VII

Metabolic Properties of Human Immunoglobulins

\begin{tabular}{lcccccc}
\hline $\begin{array}{l}\text { Immuno- } \\
\text { globulin }\end{array}$ & $\begin{array}{c}\text { Serum } \\
\text { concentration }\end{array}$ & Distribution* & $\begin{array}{c}\text { Total } \\
\text { circulating } \\
\text { pool }\end{array}$ & $\begin{array}{c}\text { Fractional } \\
\text { catabolic } \\
\text { rate }\end{array}$ & Half-life & $\begin{array}{c}\text { Synthetic } \\
\text { rate }\end{array}$ \\
\hline & $m g / m l$ & & $m g / k g$ & & Days & mg/kg/day \\
IgE & 0.0001 & 41 & 0.004 & 94.3 & 2.7 & 0.0038 \\
IgD $\$$ & 0.023 & 75 & 1.1 & 37.0 & 2.8 & 0.4 \\
IgM & 0.93 & 76 & 37.0 & 18.0 & 5.1 & 6.7 \\
IgA & 2.6 & 42 & 95.0 & 25.0 & 5.8 & 24.0 \\
IgG & 12.1 & 45 & 494.0 & 6.7 & 23.0 & 33.0 \\
\hline
\end{tabular}

* Percent intravascular of total body pool.

‡ Percent of intravascular pool per day.

$\S$ The metabolic properties of IgD, IgM, IgA, and IgG have been reported previously $(4,5)$.

The patient with an increased IgE serum level had an increased synthetic rate $(28.8 \mu \mathrm{g} / \mathrm{kg}$ per day), whereas the two patients with normal levels had synthetic rates that did not differ significantly from normal. The serum survival half-times and the fractional catabolic rates for IgE were normal in all patients. Thus, some patients with Hodgkin's disease had significantly elevated IgE levels and synthesized relatively large amounts of IgE, whereas others with this disease synthesized IgE normally; on the other hand, all patients catabolized IgE at a normal rate.

\section{DISCUSSION}

There is a wide range in the serum concentration and in the synthetic and catabolic rates of the five major classes of immunoglobulins in normal individuals $(4,5)$ (Table VII). The serum concentration of IgE in normal individuals, approximately 100 $\mathrm{ng} / \mathrm{ml}$, is markedly less than that of any of the other immunoglobulin classes. This is primarily due to the fact that the synthetic rate of $\mathrm{IgE}, 0.0038 \mathrm{mg} / \mathrm{kg}$ per day, is only $1 / 100$ th that of $\operatorname{IgD}, 1 / 1,000$ th that of $\operatorname{IgM}$, and $1 / 10,000$ that of IgA and IgG. In addition, the low serum IgE concentration is due to the fact that the fractional catabolic rate of $\operatorname{IgE}, 94 \%$ of the IV pool/day, is markedly greater than that of the other immunoglobulin classes.

Through the use of metabolic turnover studies with radioiodinated purified immunoglobulins the disorders of the immune system characterized by hypogammaglobulinemia or hypergammaglobulinemia have been shown to be due to a variety of pathophysiological mechanisms. Abnormal serum immunoglobulin levels have been shown to be due to decreased or increased synthesis of one or more classes of immunoglobulins, to accelerated endogenous catabolism of immunoglobulins, to excessive loss of immunoglobulins into the urine or gastrointestinal tract, or to a combination of these processes (5).

The abnormalities of serum IgE concentration and the underlying alterations in IgE metabolism responsible for the abnormalities in the various diseases reported here are similar, in many cases, to these observed with IgG, IgA, and IgM. In a number of instances, however, IgE concentration and metabolism are discordant with the other immunoglobulins. In part, this is a reflection of the fact that IgE synthetic rates are far lower than those of other immunoglobulin molecules, whereas fractional catabolic rates are far higher. Additionally, the discordance is related to the presence of unique mechanisms operating on IgE synthesis and catabolism, but not on other immunoglobulins.

Metabolic studies have helped establish that a generalized defect of immunoglobulin synthesis underlies the broad category of diseases known as the hypogammaglobulinemias. This category includes patients with severe combined immune deficiency in whom both B- and T-cell abnormalities are present, as well as patients with infantile $x$ linked agammaglobulinemia in whom a B-cell abnormality is present $(11-15)$. In patients with these diseases there is generalized depression of immunoglobulin levels, including IgE (16-19).

The hypogammaglobulinemias also include a large and heterogenous category of patients with socalled common variable hypogammaglobulinemia. These are patients with hyposynthetic defects of IgG, IgA, and IgM with variable times of onset, as well as variable clinical manifestations and degrees of cellular immune dysfunction. Clearly, these patients are heterogenous with regard to the basic disorder responsible for the deficiency of immunoglobulin synthesis. These disorders include defects in the maturation of stem cells into B cells, intrinsic de- 
fects in B cells that prevent their maturation into plasma cells, and defects in the secretion of immunoglobulin molecules that are synthesized $(20,21)$. In addition, we have demonstrated that some patients with common variable hypogammaglobulinemia have an abnormality of regulatory or suppressor $\mathrm{T}$ cells which act to suppress B-cell maturation and antibody production (22).

In the majority of cases, patients with common variable hypogammaglobulinemia have a markedly reduced serum IgE level and, on the basis of the metabolic turnover studies reported here, lack the ability to synthesize (or secrete) this immunoglobulin class. In these patients the pathogenetic mechanism responsible for the reduced IgE synthesis is presumably similar to that operating on the other immunoglobulin classes. It should be noted, however, that approximately $20 \%$ of the patients in the present study had an IgE level within the normal range and were able to synthesize normal quantities of IgE. The mechanism of this sparing of IgE is not known but undoubtedly is related to the fact that one or more of the underlying pathologic processes mentioned above is incomplete insofar as $\operatorname{IgE}$ is concerned. In any case, this sparing may be of clinical significance in that it appears that antibodies in the IgE immunoglobulin class, with specificity for immunoglobulins of the classes that are deficient, can be produced and may result in anaphylactic-like reactions to gammaglobulin administration or to any blood products containing immunoglobulins. (Unpublished data).

Hypogammaglobulinemia involving a reduction in polyclonal immunoglobulin levels and in the rate of immunoglobulin synthesis has been observed in patients with certain types of neoplastic disease, such as patients with benign thymomas, patients with chronic lymphocytic leukemia, and patients with multiple myeloma with IgG or IgA paraprotein. Hypogammaglobulinemia occurs in some $10 \%$ of patients with benign thymoma (23). These patients usually have an extreme reduction in immunoglobulin-bearing lymphocytes but have significant numbers of cells with the receptor for the Fc portion of the IgG molecule (24). In most patients with thymoma and hypogammaglobulinemia, essentially no IgE was present in the serum and metabolic studies showed that a disorder of IgE synthesis and not catabolism accounted for this IgE concentration defect.

The hypogammaglobulinemia associated with B-cell neoplasms, chronic lymphocytic leukemia, and multiple myeloma may be due, in part, to production by malignant classes of cells of humoral regulators of B-cell proliferation and immunoglobulin synthesis $(25,26)$. In the case of myeloma, another potential factor in the impaired synthesis of polyclonal immunoglobulins may be the presence of suppressor mononuclear cells. In this regard we have recently shown that the majority of patients with multiple myeloma had circulating phagocytic mononuclear cells that suppressed polyclonal immunoglobulin synthesis (27).

These negative pathophysiological mechanisms, whatever their precise role, affect all classes of immunoglobulins, including IgE. As shown in this study, the geometric mean serum IgE concentrations of patients with chronic lymphocytic leukemia was $18 \%$ of normal, whereas the mean value for patients with myeloma and an IgG paraprotein was $25 \%$ of normal and was $35 \%$ of normal for patients with myeloma and IgA paraprotein. Moreover, patients with these diseases and reduced serum IgE levels had pool sizes and rates of IgE synthesis that were significantly reduced. Also of interest is the fact that in patients with chronic lymphocytic leukemia the survival of IgE was slightly but significantly prolonged. The cause of this prolongation is not clear, but in view of the fact that IgE may be catabolized by a degradative mechanism not shared by the other immunoglobulins it is possible that in chronic lymphocytic leukemia this extra degradative mechanism is somewhat impaired.

In the hypogammaglobulinemia mentioned above, the pathologic process affects the synthesis of all classes of immunoglobulins, including IgE. In selective IgA deficiency, either occurring sporadically or in families, or occurring in association with ataxia telangiectasia, the synthesis of only one or, at the most, two immunoglobulins is defective. Thus, in selective IgA deficiency or in ataxia telangiectasia, only IgA concentration or IgA and IgE concentrations are subnormal, whereas the other immunoglobulin concentrations are normal.

In previous metabolic studies of selective IgA deficiency patients, decreased IgA synthesis has been found as the primary defect; in addition, in over a third of such patients antibodies to IgA have been shown to develop and, as a result, in many patients there is a markedly reduced survival of IgA (28). In patients with IgA deficiency who have anti-IgA antibody, administration of blood or blood products containing IgA may result in a severe transfusion reaction $(29,30)$. In the metabolic studies of IgE reported here we show that, as in the case of IgA, the deficiencies of IgE levels and pool size in selective IgA deficiency are due to decreased IgE synthesis; in this case, however, accelerated catabolism of IgE molecules was not demonstrated.

Thus far we have considered synthetic defects of immunoglobulin metabolism. Hypogammaglobulinemia, however, may occur as a result of catabolic de- 
fects as well, either as a disorder of an endogenous catabolic pathway or because of excessive loss of immunoglobulins into the urinary or gastrointestinal tracts. Familial hypercatabolic hypoproteinemia is an example of the first type of disorder and intestinal lymphangiectasia and protein-losing enteropathy is an example of the second type of disorder. Familial hypercatabolic hypoproteinemia is a disorder characterized by markedly reduced serum albumin and IgG levels secondary to a short survival of these proteins which is not associated with protein loss into the urinary or gastrointestinal tract (31); the origin of the endogenous catabolic defect is not known. Serum IgE concentrations in two patients with this disorder were normal, and in the one patient studied, the survival of IgE was likewise normal.

Intestinal lymphangiectasia is a disease of intestinal lymphatics occurring as a primary disorder or as a disorder secondary to cardiac or neoplastic disease. Patients with this disease lose lymph fluid containing plasma proteins and lymphocytes into the gastrointestinal tract and as a result immunodeficiency develops. In addition, they have hypoalbuminemia and hypogammaglobulinemia consequent to shortened protein survival (32). Patient with this disorder lose protein in a bulk fashion irrespective of size into the gastrointestinal tract. Thus, even very large immunoglobulin molecules, such as IgM, are lost into the intestinal tract at the same rate as the smaller molecule albumin (32). Nevertheless, as in the case of the endogenous catabolic defect studied, IgE concentration and IgE survival in these patients with gastrointestinal tract protein loss were normal. The most likely explanation for the normal serum IgE levels and survival times in these hypercatabolic states lies in the fact that the normal rate of $\operatorname{IgE}$ catabolism is so high that the increment in catabolism due to pathologic endogenous catabolism or external loss is proportionally unimportant. More specifically, if the normal rate of catabolism is $94 \%$ of the IV pool/day (as in the case of IgE) and the pathologic loss rate is $30 \%$ of the IV pool/day (as in the case of patients with intestinal lymphangiectasia studied), the predicted immunoglobulin level as a percentage of normal would be

$$
\frac{\text { normal FCR }}{\text { normal FCR + pathologic FCR }}=\frac{94}{94+30}=76 \%
$$

Thus in this case even high fractional catabolic rate has little effect on serum level. With the same analysis, it can be shown that gastrointestinal loss can have a profound effect on the serum level of IgG and other immunoglobulins; in these cases

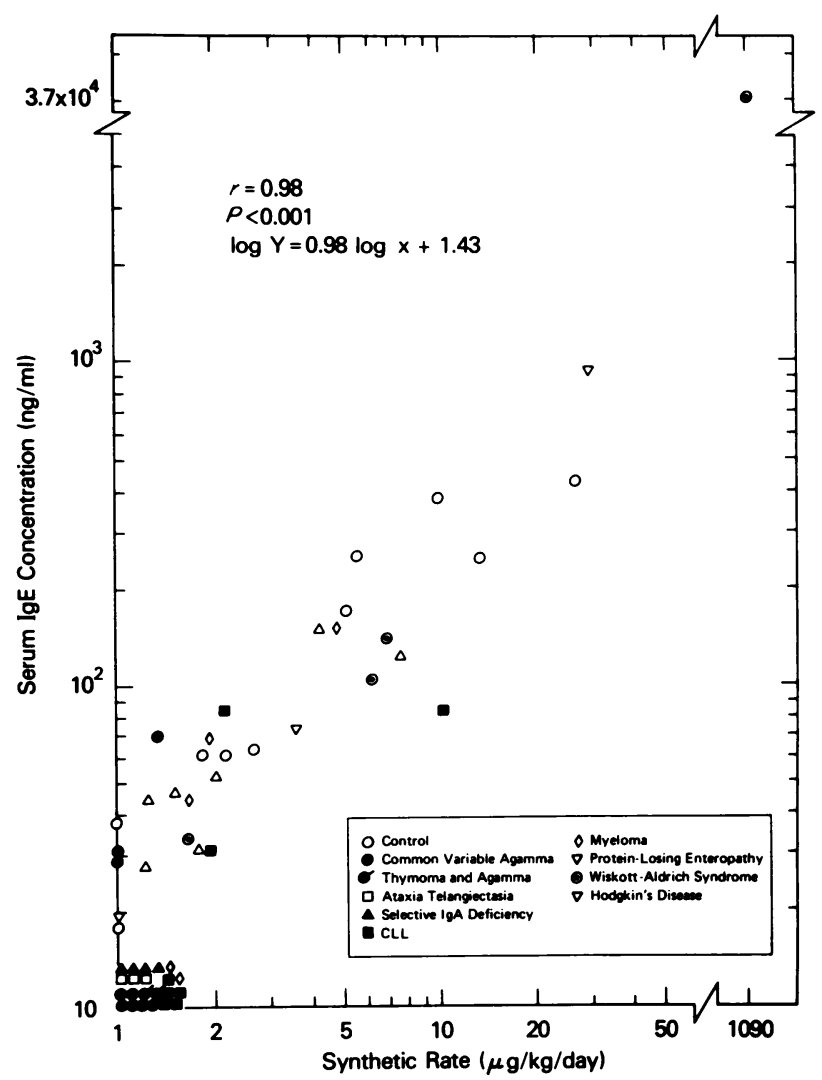

FIGURE 1 Relationship between synthetic rate of IgE and serum IgE concentration in patients with immunodeficiencies, neoplasms and hypercatabolic disorders, as well as control individuals. The statistical calculations were done by using logarithmically transformed values of synthetic rate and serum concentration of IgE.

the normal rate of catabolism is usually low relative to the pathologic rate $(6 \%$ of the IV pool/day for IgG), and the effect of a pathologic catabolic rate of $30 \%$ of the IV pool/day is to lower the serum level to $17 \%$ of normal by using the equation shown above. In summary, the groups of patients with hypogammaglobulinemia due to short immunoglobulin survival have normal IgE levels in contrast to the markedly reduced IgE levels in the majority of patients with a generalized defect of immunoglobulin synthesis. Thus, the IgE level may be of value in differentiating patients who have hypogammaglobulinemia due to hypercatabolism from those who have the same abnormalities due to decreased synthesis.

Elevated IgE levels have been noted in patients with parasitic infestations, with skin rashes, and with such allergic disorders as eczema and asthma (33-36). In the present study we examined IgE levels and IgE metabolism in two other groups of patients with elevated IgE levels, those with Hodgkin's disease and those with the Wiskott-Aldrich syndrome. In each of 
these disorders the mean IgE level was markedly elevated; however, it should be noted that whereas certain patients had exceedingly high IgE levels, other patients had IgE levels within the normal range. On the basis of the metabolic turnover studies it is clear that increased IgE synthesis was the primary factor in the elevated IgE levels observed in these patients.

Both the Wiskott-Aldrich syndrome, a disorder characterized by thrombocytopenia, eczema and an increased incidence of infections, and Hodgkin's disease are complex disorders which can result in high IgE levels on the basis of a number of possible pathophysiologic mechanisms. One possibility has as its basis the fact that both the Wiskott-Aldrich syndrome and Hodgkin's disease are associated with T-cell dysfunction $(37,38)$. Tada, Okumura, and co-workers have obtained evidence that thymic-dependent regulatory cells play a major role in terminating $\operatorname{IgE}$ antibody responses and thus can limit the synthesis of IgE generally $(39,40)$. Thus, one may postulate that in diseases where T-cell function is defective, so also may be the function of $\mathrm{T}$ cells that are normally involved in terminating IgE responses. This concept is supported by the observation that certain patients with the DiGeorge syndrome as well as certain patients with recurrent infections and impaired cellular immunity have elevated IgE levels (17).

In our examination of IgE concentration and metabolism in a variety of pathologic states we noted that there is an extreme variation in the mean serum IgE concentration. For instance, there is approximately a 1000-fold difference between the mean IgE concentration of patients with thymoma and hypogammaglobulinemia on the one hand and those with the Wiskott-Aldrich syndrome on the other hand. Indeed, the immunoglobulin level of the patients with generalized defect in immunoglobulin synthesis is approximately one ten millionth of that of the patients with IgE myeloma protein. An analysis of the relationship between the serum $\operatorname{IgE}$ concentration and the fractional catabolic rate of $\operatorname{IgE}$ or the synthetic rate of $\operatorname{IgE}$ indicates that the differences in serum IgE levels among different diseases are due predominantly to alterations in the synthetic rate of IgE. Thus, there was a highly positive correlation (Fig. 1) between the synthetic rate and the serum IgE concentration $(F=0.98, P$ $<0.001$ ). Moreover, in contrast to the observations with other immunoglobulin molecules, there were no groups of patients in whom a low IgE level was due to reduced IgE survival or a high IgE level was due to prolonged survival. This is not to say, however, that catabolic factors play no role in the control of IgE levels. We have seen (41) that extremely high IgE levels in patients with a myeloma producing an IgE paraprotein are, in fact, associated with a decreased IgE fractional catabolic rate. Rather, it is more correct to say that at the IgE concentrations seen in most pathologic states, catabolic mechanisms are not saturated and a high catabolic rate is observed, regardless of serum IgE concentration.

\section{REFERENCES}

1. Ishizaka, K., T. Ishizaka, and M. M. Hombrook, 1966. Physicochemical properties of reaginic antibody. V. Correlation of reaginic activity with $\gamma \mathrm{E}$-globulin antibody. J. Immunol. 97: 840-853.

2. Johansson, S. G. O., and H. Bennich. 1967. Immunological studies of an atypical (myeloma) immunoglobulin. Immunology. 13: 381-394.

3. Ogawa, M., S. Kochwa, C. Smith, K. Ishizaka, and O. R. McIntyre. 1969. Clinical aspects of IgE myeloma. N. Engl. J. Med. 281: 1217-1220.

4. Waldmann, T. A., and W. Strober. 1969. Metabolism of immunoglobulins. Prog. Allergy. 13: 1-110.

5. Strober, W., R. M. Blaese, and T. A. Waldmann. 1970. Abnormalities of immunoglobulin metabolism. In Plasma Protein Metabolism. Regulation of synthesis, distribution, and degradation. M. A. Rothschild, and T. A. Waldmann, editors. Academic Press, Inc., New York. 287-305.

6. McFarlane, A. S. 1958. Effective trace-labelling of proteins with iodine. Nature (Lond.). 182: 53.

7. Polmar, S. H., T. A. Waldmann, S. T. Balestra, M. C. Jost, and W. D. Terry. 1972. Immunoglobulin $E$ in immunologic deficiency diseases. I. Relation of $\operatorname{IgE}$ and IgA to respiratory tract disease in isolated IgE deficiency, IgA deficiency, and ataxia telangiectasia. J. Clin. Invest. 51: 326-330.

8. Nosslin, B. 1973. Analysis of disappearance time-curves after single injection of labelled proteins. In Protein Turnover. CIBA Foundation Symposium 9 (new series). Associated Scientific Publishers, Amsterdam, The Netherlands. 113-128.

9. Matthews, C. M. E. 1957. The theory of tracer experiments with ${ }^{131}$ I-labelled plasma proteins. Phys. Med. Biol. 2: 36-53.

10. Buckley, R. H. 1975. Clinical and immunological features of selective IgA deficiency. In Immunodeficiency in Man and Animals. D. Bergsma, R. A. Good, J. Finstad, and N. W. Paul, editors. Sinauer Associates, Inc. Sunderland, Mass. 11: 134-142.

11. Grey, H. M., E. Rabellino, and B. Pirofsky. 1971. Immunoglobulins on the surface of lymphocytes. IV. Distribution in hypogammaglobulinemia, cellular immune deficiency, and chronic lymphatic leukemia. J. Clin. Invest. 50: 2368-2375.

12. Aiuti, F., L. Fontana, and R. A. Gatti. 1973. Membrane-bound immunoglobulin (Ig) and in vitro production of $\mathrm{Ig}$ by lymphoid cells from patients with primary immunodeficiencies. Scand. J. Immunol. 2: 9-16.

13. Schiff, R. I., R. H. Buckley, R. B. Gilbertsen, and R. S. Metzgar. 1974. Membrane receptors and in vitro responsiveness of lymphocytes in human immunodeficiency. J. Immunol. 112: 376-386.

14. Hoyer, J. R., M. D. Cooper, A. E. Gabrielsen, and R. A. Good. 1968. Lymphopenic forms of congenital im- 
munologic deficiency diseases. Medicine (Baltimore). 47: 201-226.

15. Rosen, F. S., and C. A. Janeway. 1966. The gamma globulins. III. The antibody deficiency syndromes. N. Engl. J. Med. 275: 709-715.

16. McLaughlan, P., D. R. Stanworth, A. D. B. Webster, and G. L. Asherson. 1974. Serum IgE in immune deficiency disorders. Clin. Exp. Immunol. 16: 375381.

17. Buckley, R. H., and S. A. Fiscus. 1975. Serum IgD and IgE concentrations in immunodeficiency diseases. J. Clin. Invest. 55: 157-165.

18. Waldmann, T. A., S. H. Polmar, S. T. Balestra, M. C. Jost, R. M. Bruce, and W. D. Terry. 1972. Immunoglobulin $\mathrm{E}$ in immunologic deficiency diseases. II. Serum IgE concentration of patients with acquired hypogammaglobulinemia, thymoma and hypogammaglobulinemia, myotonic dystrophy, intestinal lymphangiectasia and Wiskott-Aldrich syndrome. J. Immunol. 109: 304-310.

19. Polmar, S. H., T. A. Waldmann, and W. D. Terry. 1972. IgE in immunodeficiency. Am. J. Pathol. 69: 499512.

20. Dickler, H. B., N. F. Adkinson, Jr., R. I. Fisher, and W. D. Terry. 1974. Lymphocytes in patients with variable immunodeficiency and panhypogammaglobulinemia. Evaluation of $B$ and $T$ cell surface markers and a proposed classification. J. Clin. Invest. 53: $834-840$.

21. Geha, R. S., E. Schneeberger, E. Merler, and F. S. Rosen. 1974. Heterogeneity of "acquired" or common variable agammaglobulinemia. N. Engl. J. Med. 291: $1-6$.

22. Waldmann, T. A., M. Durm, S. Broder, M. Blackman, R. M. Blaese, and W. Strober. 1974. Role of suppressor $\mathrm{T}$ cells in pathogenesis of common variable hypogammaglobulinemia. Lancet. 2: 209-613.

23. Waldmann, T. A., W. Strober, R. M. Blaese, and A. J. L. Strauss. 1967. Thymoma, hypogammaglobulinemia and absence of eosinophils. J. Clin. Invest. 46: 1127-1128. (Abstr.)

24. Siegal, F. P., P. Wernet, H. B. Dickler, S. M. Fu, and H. G. Kunkel. 1975. B lymphocytes lacking surface Ig in patients with immune deficiency: initiation of Ig synthesis in culture in cells of a patient with thymoma. In Immunodeficiency in Man and Animals. D. Bergsma, R. A. Good, J. Finstad, and N. W. Paul, editors. Sinauer Associates, Inc., Sunderland, Mass. 11: 40-44.

25. Zolla, S. 1972. The effect of plasmacytomas on the immune response of mice. J. Immunol. 108: 10391048.

26. Salmon, S. E. 1973. Immunoglobulin synthesis and tumor kinetics of multiple myeloma. Semin. Hematol. 10: $135-147$.

27. Broder, S., R. Humphrey, M. Durm, M. Blackman, B.
Meade, C. Goldman, W. Strober, and T. A. Waldmann. 1975. Impaired synthesis of polyclonal (non-paraprotein) immunoglobulins by circulating lymphocytes from patients with multiple myeloma. Role of suppressor cells. N. Engl. J. Med. 293: 887-892.

28. Strober, W., R. D. Wochner, M. H. Barlow, D. E. McFarlin, and T. A. Waldman. 1968. Immunoglobulin metabolism in ataxia telangiectasia. J. Clin. Invest. 47: 1905-1915.

29. Vyas, G. N., H. A. Perkins, and H. H. Fudenberg. 1968. Anaphylactoid transfusion reactions associated with anti-IgA. Lancet. 2: 312-315.

30. Miller, W. V., P. V. Holland, E. Sugarbaker, W. Strober, and T. A. Waldmann. 1970. Anaphylactic reactions to IgA: a difficult transfusion problem. Am. J. Clin. Pathol. 54: $618-621$.

31. Waldmann, T. A., E. J. Miller, and W. D. Terry. 1968. Hypercatabolism of IgG and albumin: A new familiar disorder. Clin. Res. 16: 45. (Abstr.)

32. Strober, W., R. D. Wochner, P. P. Carbone, and T. A. Waldmann. 1967. Intestinal lymphangiectasia: A protein-losing enteropathy with hypogammaglobulinemia, lymphocytopenia and impaired homograft rejection. J. Clin. Invest. 46: 1643-1656.

33. Ishizaka, K., and T. Ishizaka. 1967. Identification of $\gamma \mathrm{E}$-antibodies as a carrier of reaginic activity.J. Immunol. 99: $1187-1198$.

34. Johansson, S. G. O. 1967. Raised levels of a new immunoglobulin class (IgND) in asthma. Lancet. 2: 951-953.

35. Berg, T., and S. G. O. Johansson. 1969. IgE concentrations in children with atopic diseases. A clinical study. Int. Arch. Allergy Appl. Immunol. 36: 219-232.

36. Hogarth-Scott, R. S., S. G. O. Johansson, and H. Bennich. 1969. Antibodies to Toxocara in the sera of visceral larva migrans patients: the significance of raised levels of IgE. Clin. Exp. Immunol. 5: 619-625.

37. Blaese, R. M., W. Strober, R. S. Brown, and T. A. Waldmann. 1968. The Wiskott-Aldrich syndrome. A disorder with a possible defect in antigen processing or recognition. Lancet. 1: 1056-1061.

38. Eltringham, J. R., and H. S. Kaplan. 1975. Immunodeficiency in Hodgkin disease. In Immunodeficiency in Man and Animals. D. Bergsma, editor. Sinauer Associates, Inc., Sunderland, Mass. 11: 278-288.

39. Tada, T., M. Taniguchi, and K. Okumura. 1971. Regulation of homocytotropic antibody formation in the rat. II. Effect of x-irradiation. J. Immunol. 106: 1012-1018.

40. Okumura, K., and T. Tada. 1971. Regulation of homocytotropic antibody formation in the rat. III. Effect of thymectomy and splenectomy. J. Immunol. 106: 10191025.

41. Waldmann, T. A., A. Iio, M. Ogawa, O. R. McIntyre, and W. Strober. 1976. The metabolism of IgE: Studies in normal individuals and in a patient with IgE myeloma. J. Immunol. 117: 1139-1144. 